\title{
Dental Caries in Preschool Apache Indian Children
}

\author{
PETER F. INFANTE, GEORGE M. OWEN, and ALBERT L. RUSSELL \\ Center for Human Growth and Development and School of Public Health, University of \\ Michigan, Ann Arbor, Michigan 48104, USA, and Department of Pediatrics, School of \\ Medicine, University of New Mexico, Albuquerque, New Mexico 87106
}

The dearth of information regarding dental caries in white and black preschool children in the United States has resulted in estimates of cariesfree individuals ranging from $98 \%$ for the 1-year-old to $22 \%$ for the 5 -year-old child (Wisan; Lavell; and Colwell, JADA 55: 1 , 1957; Hennon; Stookey; and MUhler, JADA 79: 1405, 1969; Savara, and SuHER, J Dent Res 33: 808, 1954; INFANTE and Russell, $J$ Dent Res $53: 393,1974)$. Still less information is available regarding dental caries in preschool American Indian children. Although the sample size of the study reported here is small, the high caries attack rate at early ages seemed worthy of reporting.

In the spring of 1969 , a survey of the nutritional status of White Mountain Apache Indian children was conducted. Detailed sampling procedures, methods used, and nutritional findirigs have been reported (OWEN ET AL, in MOORE. Silverberc, and READ, Department of Health, Education, and Welfare Publication No. 72-26, 1972). The majority of the children were living in conditions of poverty or near-poverty, and housing and sanitary conditions were considered poor. The children were described as having mean intakes of energy, calcium, and vitamins $A$ and $\mathbf{B}_{2}$ substantially below those levels considered sufficient to meet needs. Protein intake was quantitatively acceptable but found to be of poor quality. The average growth in height was significantly retarded. Other than growth underachievement, conditions such as bowed legs, hair dyspigmentation, and pallor, which might be considered indications of nutritional disorders, developed in a few children.

Of the 164 children participating in medical

Received for publication July $7,1974$.

Accepted for publication January 8, 1975 .

- Present address: Division of Chronic Diseases, Ohio Department of Health, Columbus, Ohio. examinations, $96 \quad(52$ boys and 44 girls $)$ were given dental examinations. A bilingual Apache woman assisted. Only obvious lesions in which soft dentin could be detected were considered to be lesions of caries. Dental methods followed that of a previous report (INFANTE and Russell, 1974). One boy less than 1 year old and two girls just more than 6 years old were eliminated from caries analyses.

Since no sex differences in caries experience were observed, data for boys and girls were combined. As shown in the table, the mean numbers of decayed deciduous teeth and tooth surfaces as well as the percent of children who were cariesfree show a high degree of caries experience at early ages. Five-year-old children are usually reported to have an average of about four decayed deciduous teeth and about 25 to $30 \%$ were estimated to be cariesfree. Two-yearold children in this study averaged more than six decayed teeth and only $11 \%$ were cariesfree. In children two years old and younger, the greater proportion of caries activity was observed in the anterior teeth, whereas children 3 to 5 years of age had more carious teeth in the posterior segment. Linear enamel hypoplasia of the anterior teeth (19 to $39 \%$ were estimated to have developed this defect [INFANTE, Ecol Food Nutr 3: 155-156, 1974]) appeared to be associated with the high caries attack rate in the anterior teeth. Although this hypoplastic defect is rarely manifested clinically in the posterior teeth, it was observed that seven of nine children older than 2.5 years of age (usual age of completion of deciduous tooth emergence) who were positively identified as having hypoplasia in the anterior teeth also had a greater number of decayed molars than the expected-for-age in this population. Factors associated with the high attack rate in the posterior teeth at early ages in such populations would seem to merit further investigation.

TABLE

Mran def anterior and posterlor Terth, def Surdaces, and Percent Cariestrez APAChe INDUAN ChILDREN

\begin{tabular}{|c|c|c|c|c|c|c|c|c|}
\hline \multirow{2}{*}{$\begin{array}{l}\text { Age } \\
\text { (yT) }\end{array}$} & \multirow{2}{*}{$\begin{array}{c}\text { Mean } \\
\text { Age }\end{array}$} & \multirow[b]{2}{*}{$N$} & \multicolumn{4}{|c|}{ Mean def Teeth } & \multirow{2}{*}{$\begin{array}{c}\text { Mean } \\
\text { def } \\
\text { Surfaces }\end{array}$} & \multirow{2}{*}{$\begin{array}{c}\% \text { Caries } \\
\text { free } \\
\text { Subjects }\end{array}$} \\
\hline & & & Anterior & Posterior & Total & $S D$ & & \\
\hline $\begin{array}{l}1 \\
2 \\
3 \\
4 \\
5\end{array}$ & $\begin{array}{l}1.50 \\
2.54 \\
3.43 \\
4.51 \\
5.48\end{array}$ & $\begin{array}{l}14 \\
18 \\
28 \\
12 \\
21\end{array}$ & $\begin{array}{l}0.71 \\
3.72 \\
3.39 \\
2.92 \\
4.24\end{array}$ & $\begin{array}{l}0.29 \\
2.44 \\
4.82 \\
5.58 \\
5.67\end{array}$ & $\begin{array}{l}1.00 \\
6.17 \\
8.21 \\
8.50 \\
9.90\end{array}$ & $\begin{array}{l}1.52 \\
4.95 \\
4.52 \\
3.92 \\
5.17\end{array}$ & $\begin{array}{r}1.07 \\
9.61 \\
11.32 \\
12.67 \\
17.43\end{array}$ & $\begin{array}{r}64.3 \\
11.1 \\
10.7 \\
0.0 \\
9.5\end{array}$ \\
\hline
\end{tabular}

Note: Boys and girls combined. 